\title{
Influences of Landscape Configuration on River Water Quality
}

\author{
Mehdi Aalipour ${ }^{1}$, Elżbieta Antczak ${ }^{2}$ (D) Tomáš Dostál ${ }^{3}(\mathbb{D})$ and Bahman Jabbarian Amiri ${ }^{4, *}$ \\ 1 Department of Environmental Science, Faculty of Natural Resources, University of Tehran, Chamran Blvd., \\ Karaj 31587-77878, Iran; maalipour@ut.ac.ir \\ 2 Department of Spatial Econometrics, Faculty of Economics and Sociology, University of Lodz, \\ 90-255 Lodz, Poland; elzbieta.antczak@uni.lodz.pl \\ 3 Department of Landscape Water Conservation, Faculty of Civil Engineering, Czech Technical University \\ in Prague, Thakurova 7, 16629 Prague, Czech Republic; dostal@fsv.cvut.cz \\ 4 Department of Regional Economics and the Environment, Faculty of Economics and Sociology, \\ University of Lodz, 90-255 Lodz, Poland \\ * Correspondence: bahman.amiri@uni.lodz.pl
}

Citation: Aalipour, M.; Antczak, E.; Dostál, T.; Jabbarian Amiri, B.

Influences of Landscape

Configuration on River Water Quality.

Forests 2022, 13, 222. https://

doi.org/10.3390/f13020222

Academic Editor: Steven McNulty

Received: 8 December 2021

Accepted: 27 January 2022

Published: 1 February 2022

Publisher's Note: MDPI stays neutral with regard to jurisdictional claims in published maps and institutional affiliations.

Copyright: () 2022 by the authors Licensee MDPI, Basel, Switzerland. This article is an open access article distributed under the terms and conditions of the Creative Commons Attribution (CC BY) license (https:/ / creativecommons.org/licenses/by/ $4.0 /)$.

\begin{abstract}
The present study investigated the effects of changes in landscape configuration on river water quality, which is calculated by chemical export coefficients, using spatial data onto 31 catchments in the southwestern part of the Caspian Sea basin by applying stepwise multivariate regression models. The water quality modeling has been carried out applying the chemical export coefficients of sulfate, bicarbonate, chlorine, calcium, magnesium, and sodium, and eight landscape metrics (including interspersion juxtaposition index, percentage of like adjacencies, aggregation index, clumpiness index, normalized landscape shape index, patch cohesion index, landscape division index, and splitting index), by which landscape configuration is analyzed. The results indicated that the sulfate $\left(0.25 \pm 0.33 \mathrm{gr} \mathrm{ha}^{-1} \mathrm{yr}^{-1}\right)$, bicarbonate $\left(0.61 \pm 0.87 \mathrm{gr} \mathrm{ha}^{-1} \mathrm{yr}^{-1}\right)$, chlorine $\left(0.17 \pm 0.23 \mathrm{gr} \mathrm{ha}^{-1} \mathrm{yr}^{-1}\right)$, calcium $\left(0.16 \pm 0.21 \mathrm{gr} \mathrm{ha}^{-1} \mathrm{yr}^{-1}\right)$, magnesium $\left(0.05 \pm 0.07 \mathrm{gr} \mathrm{ha}^{-1} \mathrm{yr}^{-1}\right)$, and sodium $\left(0.16 \pm 0.21 \mathrm{gr} \mathrm{ha}^{-1} \mathrm{yr}^{-1}\right)$ are annually exported from the study catchments into the rivers. The change in landscape configuration has significantly explained the chemical export coefficients of sulfate, bicarbonate, chlorine, calcium, magnesium, and sodium. The findings showed the cohesion and coherence of the permanently irrigated land patches resulting in the discontinuity of the broad-leaved forest and grassland ecosystems degraded river water quality.
\end{abstract}

Keywords: river water quality; chemical export coefficient; landscape configuration; landscape metrics

\section{Introduction}

The impacts of change in land use/land cover patterns on aquatic environments are one of the most critical subjects and crises in water resource management and environmental science [1]. River water quality plays an essential role in human health [2,3]. Therefore, identifying the main factors that affect river water quality [4] and their relative contribution among others can be considered as an inevitable necessity. The quality of water rivers are controlled by different characteristics of catchments, out of which might be pointed to topography [5], land use/land cover changes [6], landscape [7], soil [8], geology [9], impervious area [10] drainage density [11], temperature [12] agricultural areas [13], and urban development [11].

The relationship between change in land use/land cover and river water quality variables were well-documented in the studies, e.g., see: [14-16], in which the influence of the spatial patterns of land use/land cover on river water quality was addressed. Land use/land cover change due to socio-economic development is one of the significant inevitable consequences that cause the landscape to be fragmented into natural and manmade patches [17]. Change in the spatial pattern of land use/land cover not only disrupts 
natural processes in general but also causes them to emerge in irregularities in vital energy, water, and nutrient cycles in particular [11,18].

A landscape is mainly described by three characteristics: composition, structure, and configuration [19]. While the type and area of land use/land cover classes, and the shape of their patches are addressed in the landscape composition and structure, respectively; the neighborhood, proximity, and cohesion of landscape patches are in the focus of attention of landscape configuration. Hence, it is the spatial arrangement of the patches of a given land use/land cover type relative to the same or uneven patches that are considered by landscape configuration [20,21].

The study of landscape configuration is mainly based on how and to what degree a given function of the landscape can be derived from spatial relationships between various shapes of land use and land cover patches within a catchment. Landscape metrics can provide reliable information and practical guidelines to develop more environmentally sound approaches to improve the quantity and quality of water resources [22-24].

Landscape configuration is mainly analyzed and addressed by interspersion juxtaposition index [13], patch cohesion index [25-27], splitting index [25], percentage of like adjacencies, aggregation index [21,28], clumpiness index [26], normalized landscape shape index [27], and landscape division index. The interspersion juxtaposition index calculates the shrinkage of patches based on the proximity $[21,28]$. Patch cohesion index is defined by the ratio of the parameter to the average area of the shape index which is adjusted by area [21,29]. Splitting index refers to the number of patches of the same size of a particular class to create a desirable amount of land distribution and depends on the degree of land distribution [30].

To conduct the present study, we were inspired by the concept of chemical export coefficient (CEC), which is by definition the nutrient or chemical loads that are exported from the area of different land use/land cover classes over the catchment. This concept was initially introduced in the 1970s (e.g.,: [31,32]) to predict the nutrient loads of streams and lakes in North America [31,33]. It is expressed in terms of weight unit for a given area and over a specific time period (e.g.: $\mathrm{gr} \mathrm{ha}^{-1} \mathrm{yr}^{-1}$ ). It was used for export coefficient-based modeling of phosphate and nitrogen loads estimation from catchment [34,35]. Johns (1996) and Mattikali and Richards (1996) applied it to determine the nutrients (nitrogen and phosphorus concentrations) released from catchment land use/land cover types [36,37].

Simplicity in the structure and application, low data requirements, and the costeffectiveness of calibrating and validating practices [38,39], along with providing acceptable accuracy to practitioners [40], are considered to be among the main advantages of the CECs due to which it has been widely applied to study the relationship between land use/land cover types and in-stream water quality for large-sized catchments [41,42].

There are few studies (e.g., see: $[43,44]$ ) that address the impacts of landscape configuration on instream water quality. Hence, it is very difficult to discuss the possible effects of landscape configuration on river water quality since so far understanding the effects that landscape configuration might have on river water quality has not drawn the necessary attention. Accordingly, there are no well-documented answers to this crucial question that to what extent landscape configuration would affect stream water quality. Therefore, it becomes increasingly necessary to conduct studies in this area to fill out this gap. Hence, the main objectives of this study are: (1) to examine whether there is a significant relationship between landscape configuration and instream water quality; (2) to find out to what extent change in landscape configuration affect instream water quality; and (3) to assess whether instream water quality could be predicted by change in landscape configuration of the catchments.

\section{Material and Methods}

\subsection{Study Area}

Thirty-one catchments, with an area ranging between 3.73 to $3242.67 \mathrm{~km}^{2}$. and a mean annual discharge of $2.12 \pm 1.46\left(\mathrm{~m}^{3} \mathrm{~s}^{-1}\right)$, located in the southwestern part of the Caspian Sea basin, have been selected considering the availability of the data for this study. The catchments are situated in varying elevations ranging between 244 to 2499 m.s.l. The 
annual mean of precipitation and temperature is $324 \mathrm{~mm} \cdot \mathrm{yr}^{-1}$ and $12{ }^{\circ} \mathrm{C}$, respectively. The dominant land use/land cover types are moderate-density grassland (G2) (39\%), nonirrigated arable land (Ra) (33\%), and permanently irrigated land (Ir) (13\%). Figure 1 shows the geographical location of the study catchments.

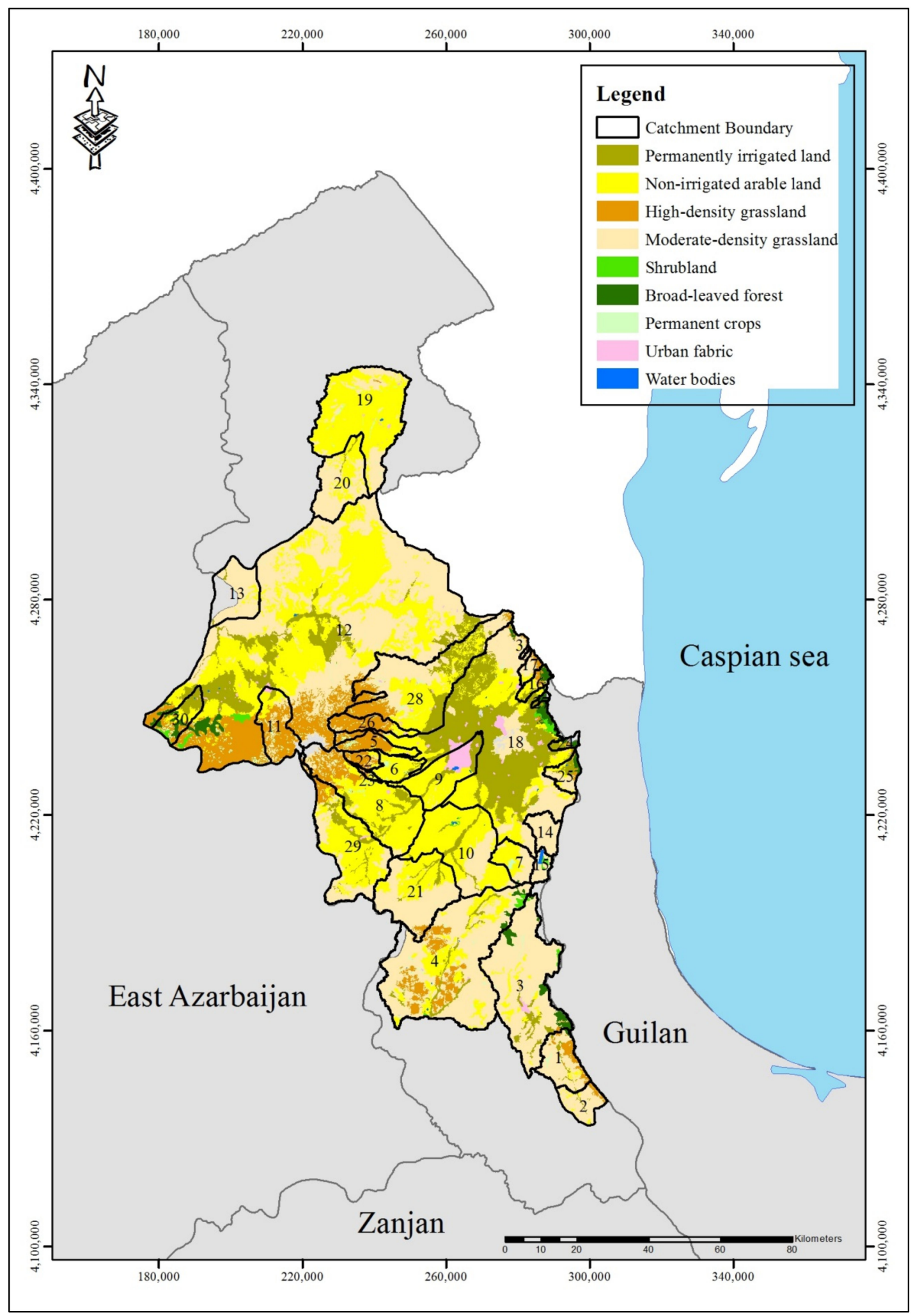

Figure 1. Location of the study catchments. 


\subsection{Data Collection}

The river water quality data were obtained from the regional authority of water resources management. The land use/land cover map (scale: 1:25,000) was acquired from the Ardabil Management and Planning Organization [45]. The digital elevation model (scale: 1:50,000) was received from the Iran National Cartographic Center [46]. To delineate the boundary of study catchments, the digital elevation model (DEM) [46] was applied; the resultant catchment boundaries were then controlled by the topographic maps $(1: 50,000)$ of the study area [46]. The land use/land cover map [45] was reclassified into nine classes according to the Corine land use/land cover nomenclature [47], which includes permanently irrigated land (Ir), non-irrigated arable land (Ra), urban fabric area (Ur), high-density grassland (G1), moderate-density grassland (G2), broad-leaved forest (Fr), permanent crops [orchard (Or)], water bodies ( $\mathrm{Wb})$, and shrubland(Sh). The resultant map was intersected by the boundary map of the catchments, aiming to calculate the value of the landscape configuration-describing metrics. The four years mean values (2010-2013) of water quality variables, which include sulfate $\left(\mathrm{SO}_{4}{ }^{2-}\right)$, bicarbonate $\left(\mathrm{HCO}^{3-}\right)$, chlorine $\left(\mathrm{Cl}^{-}\right)$, calcium $\left(\mathrm{Ca}^{2+}\right)$, magnesium $\left(\mathrm{Mg}^{2+}\right)$, and sodium $\left(\mathrm{Na}^{+}\right)$were applied to examine the relationship between change in water quality variables and change in the landscape configuration of the catchments.

\subsection{Methodology}

\subsubsection{Landscape Configuration Metrics}

Landscape configuration metrics [21,48,49], which include interspersion juxtaposition index, percentage of like adjacencies, aggregation index, clumpiness index, normalized landscape shape index, patch cohesion index, landscape division index, and splitting index, were calculated for each land-use type in the study catchments. Each of the landscape metrics was determined for the nine land use/land cover types (permanently irrigated land, non-irrigated arable land, urban fabric area, high-density grassland, moderate-density grassland, broad-leaved forest, permanent crops, water bodies, and shrubland). For instance, the interspersion juxtaposition index (IJI) calculated for all the land use/land cover types includes $\mathrm{IJI}_{\mathrm{Ir}}, \mathrm{IJI}_{\mathrm{Ra}}, \mathrm{IJI}_{\mathrm{Ur}}, \mathrm{IJI}_{\mathrm{G} 2}, \mathrm{IJI}_{\mathrm{G} 1}, \mathrm{IJI}_{\mathrm{Fr}}, \mathrm{IJI}_{\mathrm{Or}}, \mathrm{IJI}_{\mathrm{WB}}$, and $\mathrm{IJI}_{\mathrm{Sh}}$. Table 1 provides the details on the definition, range, and formula for each of the landscape metrics.

\subsubsection{MLR Modeling}

The relationship between water quality variables and landscape configuration metrics was initially examined using the Pearson correlation test $(p \leq 0.01)$, aiming to find out whether there is any collinearity $(r \geq 0.8)$ between the variables. Multivariate regression modeling (MLR) has been applied through the stepwise [52] approach to developing models, by which the CECs could be predicted using spatial data from the catchments. To perform MLR analysis, available data were divided by the proportion of $70 \%$ to $30 \%$ for model calibration and validation purposes, respectively. Moreover, four model structures, which include linear, logarithmic, exponential, and power types [14], were tested aiming to find out which one of the model structures was the most appropriate model, by which the instream water quality could reliably be predicted by the landscape configuration metrics.

To model the relationship between instream water quality and the configuration of land use/land cover types, we applied the concept of nutrient export coefficient to calculate the CECs (gr ha ${ }^{-1} \mathrm{yr}^{-1}$ ) of $\mathrm{SO}_{4}, \mathrm{HCO}_{3}, \mathrm{Cl}, \mathrm{Ca}, \mathrm{Mg}$, and $\mathrm{Na}$, as water quality variables using Equation (1) [53], as follows:

$$
\mathrm{L}=\int_{0}^{\mathrm{T}} \mathrm{QCdt}
$$

where $Q$ is river discharge $\left(\mathrm{m}^{3} \mathrm{~s}^{-1}\right), \mathrm{C}$ is the nutrient concentration $(\mathrm{mg} / \mathrm{L})$, and $\mathrm{T}$ is time (s). Sulfate, bicarbonate, chlorine, calcium, magnesium, and sodium are measured in 
mili equivalent per liter. The values were firstly transformed into those of $\mathrm{mg} \mathrm{L}^{-1}$ applying the Equation (2), as follows:

$$
m=(m E q \cdot M W) / V E
$$

where, $m$ is mass in milligram, $m E q$ stands for milliequivalent, $M W$ is molecular weight, and $V E$ is valence electron. The annual mass of the sulfate, bicarbonate, chlorine, calcium, magnesium, and sodium was then divided by the catchment area to produce the CECs of water quality variable in $\mathrm{gr} \mathrm{ha}^{-1} \mathrm{yr}^{-1}$. Collinearity among the independent variables of the models was then investigated by the value of variance inflation factor [54]. This factor examines the collinearity between two independent variables. To screen the thirty-two potential models for each of the CECs aiming to determine which model(s) are the most appropriate ones that describe the considerable part of total variations in the in-stream water quality, Akaike Information Criterion was applied to an intermodal comparison. Akaike Information Criterion Equation (3) determines the closest model to system reality and comprises and selects the most appropriate model from a set of calibrated models that fits well and has fewer variables [55]:

$$
\mathrm{AIC}_{\mathrm{c}}=\mathrm{n}\left(\log \frac{\mathrm{RSS}}{\mathrm{n}}\right)+2 \mathrm{~K}+\left(\frac{2 \mathrm{k}(\mathrm{K}+1)}{\mathrm{n}-\mathrm{K}-1}\right)
$$

where AIC is the value of the Akaike Information Criterion, $\mathrm{K}$ is the number of model variables including the constant of a model, $\mathrm{n}$ is the number of samples, and RSS stands for the sum of model error squares [56]. One by one scatter plots [57] were also drawn, applying the observed and predicted values of the water quality variables to examine whether at least $75 \%$ of the values are bounded within a $95 \%$ confidence boundary [58]. All statistical analyses were performed by SPSS version 17.

\begin{tabular}{|c|c|c|}
\hline Metric & Description & Formula \\
\hline Interspersion Juxtaposition Index & $\begin{array}{l}\text { According to the metric, the values of zero indicate the } \\
\text { disproportionate distribution of patches proximity, and } \\
\text { for values of } 100 \text {, it indicates that all types of patches } \\
\text { are perfectly equal in proximity [50]. }\end{array}$ & $I J I=\frac{-\sum_{k=1}^{m}\left[\left(\frac{e_{i k}}{\sum_{k=1}^{m} e_{i k}}\right) \ln \left(\frac{e_{i k}}{\sum_{k=1}^{m} e_{i k}}\right)\right]}{\operatorname{Ln}(m-1)}(100)$ \\
\hline $\begin{array}{l}\text { Percentage of Like Adjacencies } \\
\text { (PLADJ) }\end{array}$ & $\begin{array}{l}\text { A value of zero indicates that the patch has the } \\
\text { maximum division (each cell has different patches), } \\
\text { and there is no proximity, and the value of } 100 \\
\text { indicates that the landscape contains one type of patch. }\end{array}$ & $P L A D J=\left(\frac{g_{i i}}{\sum_{k=1}^{m} g_{i k}}\right)(100)$ \\
\hline Aggregation index (AI) & $\begin{array}{l}\text { The value change from zero when no similar or } \\
\text { marginal proximity (classes are severely fragmented) } \\
\text { to } 1 \text { at the highest value with pixels having the largest } \\
\text { possible edge (classes fully collapsed) [49] }\end{array}$ & $A I=\left(\frac{g_{i i}}{\max \rightarrow g_{i i}}\right)(100)$ \\
\hline Clumpiness index (CI) & $\begin{array}{l}\text { This metric changes from a value of }-1 \text { (completely } \\
\text { fragmented) to } 1 \text { (maximum aggregation) [51]. }\end{array}$ & $\begin{array}{c}\text { CLUMPY }= \\
{\left[\frac{G_{i}-P_{i}}{P_{i}} \text { for } G_{i}<P_{i} \& P_{i}<0.5 ; \text { else } \frac{G_{i}-P_{i}}{1-P_{i}}\right]}\end{array}$ \\
\hline $\begin{array}{l}\text { Normalized Landscape Shape } \\
\text { index (NLSI) }\end{array}$ & $\begin{array}{l}\text { The values range from } 0 \text { to one that values close to one } \\
\text { indicate high levels of internal margins and low } \\
\text { patch aggregation. }\end{array}$ & $N L S I=\frac{e_{i}-\text { mine }_{i}}{\max _{i}-\text { mine }_{i}}$ \\
\hline Patch Cohesion Index (PCI) & $\begin{array}{l}\text { The metric zero value is when the class patches are } \\
\text { very isolated. Metric value increase when the class } \\
\text { patches are much more aggregated }[29,48] .\end{array}$ & Cohesion $=\left[1-\frac{\sum_{i=1}^{m} P_{i j}}{\sum_{i=1}^{m} P_{i j} \sqrt{a_{i j}}}\right]\left[1-\frac{1}{\sqrt{A}}\right]^{-1} \times 100$ \\
\hline Landscape Division Index (LDI) & $\begin{array}{l}\text { Metric value varies between } 0 \text { and } 1 \text {. The zero value } \\
\text { indicates a patch in the landscape. }\end{array}$ & Division $=\left[1-\sum_{j=1}^{n}\left\{\frac{a_{i j}}{A}\right\}^{2}\right] \times 100$ \\
\hline Splitting Index (SI) & $\begin{array}{l}\text { The metric value equal to } 1 \text { indicate landscape consists } \\
\text { of only one patch. Moreover, when the patch is divided } \\
\text { into smaller patches, the value of the metric increase. }\end{array}$ & $S P L I T=\frac{A^{2}}{\sum_{i=1}^{m} \sum_{j=1}^{n} a_{i j}{ }^{2}}$ \\
\hline
\end{tabular}

Table 1. Description, ranges, and formulas of the landscape configuration metrics. 


\subsubsection{Model Validation}

To validate the appropriate model for a given water quality variable, three groups of model validation metrics, which include relative error metrics (mean relative error, mean absolute relative error, and relative volumetric error), efficiency metrics (coefficient of determination, consistency index, and coefficient of efficiency), and absolute error metrics (root mean square error, mean error, mean absolute error, and peak difference) were applied [59]. Table 2 provides more details on the formulas and range of the validation metrics. More details about the validation metrics can be found in Dawson et al. (2007) [59].

Table 2. Formulas and ranges of the validation metrics.

\begin{tabular}{|c|c|c|c|}
\hline Type & Metric & Equation & Range \\
\hline \multirow{4}{*}{ 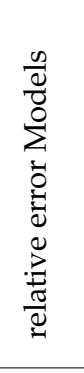 } & Mean relative error (MRE) & $\mathrm{MRE}=\frac{1}{\mathrm{n}} \sum_{\mathrm{i}=1}^{\mathrm{n}}\left(\frac{\mathrm{O}_{\mathrm{i}}-\mathrm{P}_{\mathrm{i}}}{\mathrm{O}_{\mathrm{i}}}\right)^{2}$ & $0-\infty$ \\
\hline & Mean Absolute Relative Error (MARE) & MARE $=\frac{1}{n} \sum_{i=1}^{n} \frac{\left|\mathrm{O}_{\mathrm{i}}-\mathrm{P}_{\mathrm{i}}\right|}{\mathrm{O}_{\mathrm{i}}}$ & $0-\infty$ \\
\hline & Relative Absolute Error (RAE) & $\mathrm{RAE}=\sum_{\mathrm{i}=1}^{\mathrm{n}}\left(\left|\mathrm{O}_{\mathrm{i}}-\mathrm{P}_{\mathrm{i}}\right| / \sum_{\mathrm{i}=1}^{\mathrm{n}}\left|\mathrm{O}_{\mathrm{i}}-\overline{\mathrm{O}}\right|\right.$ & $0-\infty$ \\
\hline & Relative Volumetric Error (RVE) & $R V E=\sum_{i=1}^{n}\left(O_{i}-P_{i}\right) / \sum_{i=1}^{n} O_{i}$ & $0-\infty$ \\
\hline \multirow{3}{*}{ 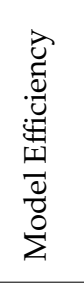 } & Coefficient of Determination $\left(\mathrm{r}^{2}\right)$ & $\mathrm{r}^{2}=\frac{\mathrm{n}\left(\sum \mathrm{xy}\right)-\left(\sum \mathrm{x}\right)\left(\sum \mathrm{y}\right)}{\sqrt{\left[\mathrm{n} \sum \mathrm{x}^{2}-\left(\sum \mathrm{x}\right)^{2}\right]\left[\mathrm{n} \sum \mathrm{y}^{2}-\left(\sum \mathrm{y}\right)^{2}\right]}}$ & $0-1$ \\
\hline & Consistency Index (IA) & $I A=\sum_{i=1}^{n}\left(O_{i}-P_{i}\right) / \sum_{i=1}^{n}\left(\left|P_{i}-\bar{O}\right|+\left|O_{i}-\bar{O}\right|\right)^{2}$ & $0-\infty$ \\
\hline & Coefficient of Efficiency (CE) & $C E=1-\sum_{i=1}^{n}\left(O_{i}-P_{i}\right)^{2} / \sum_{i=1}^{n}\left(O_{i}-\bar{O}\right)^{2}$ & $0-\infty$ \\
\hline \multirow{4}{*}{ 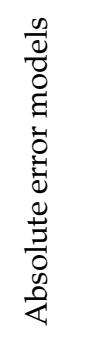 } & Root Mean Square Error (RMSE) & RMSE $=\sqrt{\sum_{i=1}^{n}\left(O_{i}-P_{i}\right)^{2} / n}$ & $0-\infty$ \\
\hline & Mean Error (ME) & $\mathrm{ME}=\frac{1}{\mathrm{n}} \sum_{\mathrm{i}=1}^{\mathrm{n}}\left(\mathrm{O}_{\mathrm{i}}-\mathrm{P}_{\mathrm{i}}\right)$ & $0-\infty$ \\
\hline & Mean absolute error (MAE) & $\mathrm{fMAE}=\frac{1}{\mathrm{n}} \sum_{\mathrm{i}=1}^{\mathrm{n}}\left|\mathrm{O}_{\mathrm{i}}-\mathrm{P}_{\mathrm{i}}\right|$ & $0-\infty$ \\
\hline & Peak difference (PDIFF) & $P D I F F=\max \left(O_{i}\right)-\max P_{i}$ & $0-\infty$ \\
\hline
\end{tabular}

Source: Dawson et al. (2007) [59].

\subsubsection{Uncertainty Analysis}

Model uncertainty analysis is a critical step in modeling as it allows us to understand how models behave in different conditions. In particular, uncertainty analysis focuses on obtaining the potential results of the model taking into account all possible uncertainties in input variables [60]; therefore, to determine how appropriate models in this study could be applied for predicting the instream water quality at the catchment scale, an uncertainty analysis was performed using the Monte Carlo simulation approach. Monte Carlo simulation performed according to the following steps: (1) defining the model; (2) determining the descriptive statistics of the model variables; (3) determining the best fitted statistical distribution for the variables of the model; (4) generating random data (for this study, was 15,000) based on the statistics of the fitted statistical distributions for the model independent variables; (5) simulating the model responses using the generated data; and (6) analyzing the behaviors of the models probabilistically [14].

\section{Results}

\subsection{Result of Landscape Configuration}

Calculating the landscape composition metrics indicated that the dominant land use/land cover type is the moderate-density grassland (39\%) and the sub-dominant one 
is the non-irrigated arable land (33\%). The permanent crops as fruit trees plantations (orchards), water bodies, and shrublands each make up one percent of the land use/land cover composition. Moreover, the moderate-density grassland along with the non-irrigated arable land and the permanent crops were observed to have the highest value in the patch density in the study catchments (Table 3).

Table 3. Results of the landscape composition metrics for the study catchments.

\begin{tabular}{cccc}
\hline Land Use/Land Cover Type & $\begin{array}{c}\text { Area } \\
\text { (\%) }\end{array}$ & $\begin{array}{c}\text { Patch Density } \\
\text { (Patch Number. } \mathbf{k m}^{-2} \text { ) }\end{array}$ & $\begin{array}{c}\text { Mean Patch Area } \\
\text { (ha.) }\end{array}$ \\
\hline Permanently irrigated land & 12.95 & 0.008 & 633.54 \\
Non-irrigated arable land & 33.97 & 0.0286 & 456.98 \\
Urban fabric & 1.03 & 0.0071 & 57.53 \\
High-density grassland & 9.44 & 0.0106 & 350.02 \\
Moderate-density grassland & 39.80 & 0.031 & 504.54 \\
Broad-leaved forest & 1.39 & 0.0015 & 372.15 \\
Permanent crops & 0.87 & 0.0211 & 16.24 \\
Water bodies & 0.09 & 0.0009 & 39.70 \\
Shrubland & 0.46 & 0.0004 & 491.47 \\
\hline
\end{tabular}

The result of landscape configuration metrics, which were calculated using land use/land cover map, were depicted using three statistics, including mean and the upper and lower standard deviations (Figure 2).
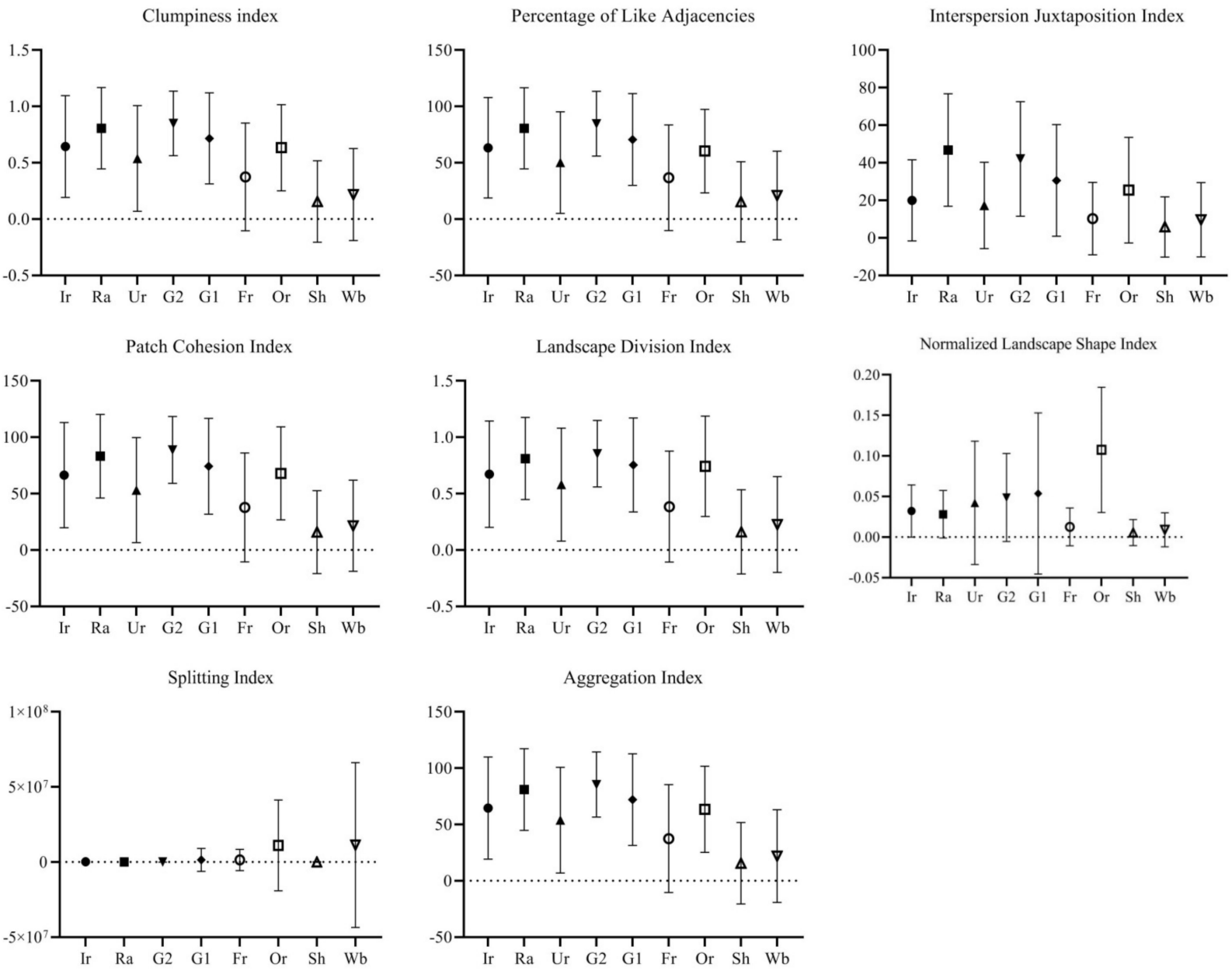

Figure 2. The box-plot of the landscape metrics of the land use/land cover types. (Ir: permanently irrigated land, Ra: non-irrigated arable land, Ur: urban fabric area, G1: high-density grassland, G2: moderatedensity grassland, Fr: broad-leaved forest, Or: permanent crops, Sh: shrubland, Wb: water body). 


\subsection{Result of Chemical Export Coefficients}

The results indicated that the sulfate $\left(0.25 \pm 0.33 \mathrm{gr} \mathrm{ha}^{-1} \mathrm{yr}^{-1}\right)$, bicarbonate $\left(0.61 \pm 0.87 \mathrm{gr} \mathrm{ha}^{-1} \mathrm{yr}^{-1}\right)$, chlorine $\left(0.17 \pm 0.23 \mathrm{gr} \mathrm{ha}^{-1} \mathrm{yr}^{-1}\right)$, calcium $\left(0.16 \pm 0.21 \mathrm{gr} \mathrm{ha}^{-1} \mathrm{yr}^{-1}\right)$, magnesium $\left(0.05 \pm 0.07 \mathrm{gr} \mathrm{ha}^{-1} \mathrm{yr}^{-1}\right)$, and sodium $\left(0.16 \pm 0.21 \mathrm{gr} \mathrm{ha}^{-1} \mathrm{yr}^{-1}\right)$ are annually exported from the terrestrial ecosystems of the study catchments into the rivers. Figure 3 indicates the box-plot of the CECs of sulfate, bicarbonate, chlorine, calcium, magnesium, and sodium.

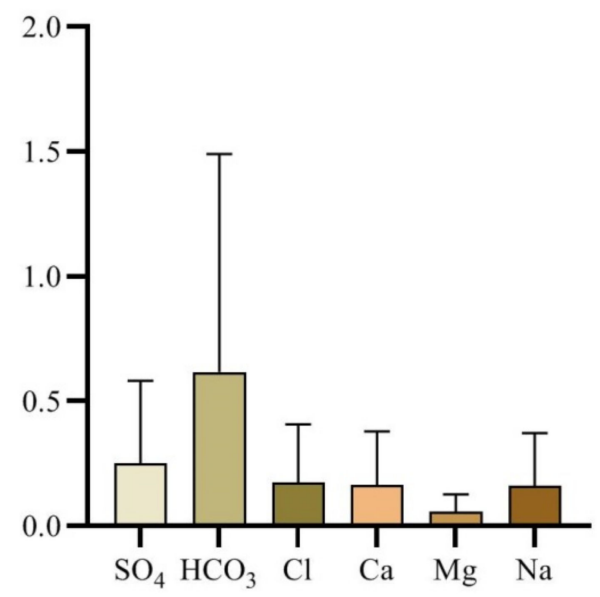

Figure 3. Box-plot of the CECs of water quality parameters for the study catchments.

\subsection{Bivariate Analyses}

Table 4 shows the results of the Pearson correlation test $(p \leq 0.01)$ between the CECs of six water quality variables $\left(\mathrm{SO}_{4}, \mathrm{HCO}_{3}, \mathrm{Cl}, \mathrm{Ca}, \mathrm{Mg}\right.$, and $\left.\mathrm{Na}\right)$ and the mean values of the landscape configuration metrics. The collinearity $\left(\mathrm{r}^{2} \geq 0.8\right)$ between the landscape configuration metrics as independent variables of the models can be addressed, aiming to be set aside for further steps in modeling.

Table 4. Results of the Pearson correlation test between CEC variables and landscape configuration metrics.

\begin{tabular}{|c|c|c|c|c|c|c|c|c|c|c|c|c|c|c|}
\hline & $\mathrm{SO}_{4}$ & $\mathrm{HCO}_{3}$ & $\mathrm{Cl}$ & $\mathrm{Ca}$ & Mg & $\mathrm{Na}$ & CI & PLADJ & IJI & PCI & LDI & SI & AI & NLSI \\
\hline $\begin{array}{l}\mathrm{SO}_{4} \\
\mathrm{HCO}_{3}\end{array}$ & $\begin{array}{c}1 \\
0.60^{* *}\end{array}$ & 1 & & & & & & & & & & & & \\
\hline $\mathrm{Cl}$ & 0.89 ** & $0.83^{* *}$ & 1 & & & & & & & & & & & \\
\hline $\mathrm{Ca}$ & $0.71 * *$ & $0.98^{* *}$ & $0.89^{* *}$ & 1 & & & & & & & & & & \\
\hline $\mathrm{Mg}$ & 0.80 ** & 0.95 ** & 0.94 ** & $0.98 * *$ & 1 & & & & & & & & & \\
\hline $\mathrm{Na}$ & 0.95 ** & $0.77^{* *}$ & $0.96^{* *}$ & 0.83 ** & $0.89^{* *}$ & 1 & & & & & & & & \\
\hline CI & 0.01 & 0.21 & 0.11 & 0.16 & 0.13 & 0.14 & 1 & & & & & & & \\
\hline PLADJ & 0.08 & 0.21 & 0.14 & 0.17 & 0.16 & 0.18 & $0.91 * *$ & 1 & & & & & & \\
\hline IJI & -0.27 & -0.21 & -0.30 & -0.26 & -0.30 & -0.24 & -0.09 & -0.10 & 1 & & & & & \\
\hline PCI & 0.16 & 0.22 & 0.19 & 0.20 & 0.20 & 0.21 & $0.85^{* *}$ & $0.94^{* *}$ & -0.14 & 1 & & & & \\
\hline LDI & 0.18 & -0.01 & 0.13 & 0.01 & 0.05 & 0.16 & 0.04 & 0.08 & $\begin{array}{l}-0.21 \\
-0.21\end{array}$ & 0.03 & 1 & & & \\
\hline SI & 0.02 & -0.11 & -0.03 & -0.08 & -0.07 & -0.02 & -0.11 & -0.22 & -0.14 & -0.19 & 0.11 & 1 & & \\
\hline $\mathrm{AI}$ & 0.04 & 0.23 & 0.15 & 0.19 & 0.16 & 0.17 & $0.99 * *$ & $0.92 * *$ & -0.08 & $0.87 * *$ & 0.03 & -0.13 & 1 & \\
\hline NLSI & -0.04 & -0.24 & -0.15 & -0.19 & -0.17 & -0.17 & $-0.99 * *$ & $-0.92 * *$ & 0.08 & $-0.87 * *$ & -0.03 & 0.13 & $-0.99 * *$ & 1 \\
\hline
\end{tabular}

** Significant on 0.01; CI: Clumpiness Index, PLADJ: Percentage of Like Adjacencies, IJI: Interspersion Juxtaposition Index, PCI: Patch Cohesion Index, LDI: Landscape Division Index, SI: Splitting Index, AI: Aggregation Index, and NLSI: Normalized Landscape Shape Index.

\subsection{Result of Modeling}

The results of the inter-model comparison, which was conducted by Akaike Information Criterion, indicated that the most appropriate regression model significantly explaining the variance in CECs of sulfate, bicarbonate, chlorine, magnesium, and sodium has the power structure, while the case for calcium has a logarithmic one. Equations (4)-(9) showed that three out of eight landscape metrics, which include interspersion juxtaposition index, patch cohesion index, and splitting index, can play a significant role in explaining the 
change in the CECs of the sulfate, bicarbonate, chlorine, calcium, magnesium, and sodium. Table 5 provides more details about the statistics of the models. The models explained a varying percentage ( $43-57 \%)$ of the total variations in the water quality variables, as follows:

$$
\begin{gathered}
\log C E C_{\mathrm{SO}_{4}}=-0.404 \log \left(\mathrm{IJI}_{\mathrm{G} 2}\right)-0.547 \log \left(\mathrm{IJI}_{\mathrm{G} 1}\right)-0.28 \\
\log C E C_{\mathrm{HCO}_{3}}=0.168 \log \left(\mathrm{PCI}_{\mathrm{Or}}\right)+0.135 \log \left(\mathrm{PCI}_{\mathrm{Wb}}\right)+2.537 \\
\log C E C_{\mathrm{Cl}}=-0.129 \log \left(\mathrm{SI}_{\mathrm{Ir}}\right)-0.724 \\
C E C_{\mathrm{Ca}}=-0.122 \log \left(\mathrm{SI}_{\mathrm{Ir}}\right)-0.71 \\
\log C E C_{\mathrm{Mg}}=-0.149 \log \left(\mathrm{IJI}_{\mathrm{G} 2}\right)+0.283 \\
\log C E C_{\mathrm{Na}}=-0.406 \log \left(\mathrm{IJI}_{\mathrm{G} 2}\right)-0.496
\end{gathered}
$$

where:

CEC the chemical export coefficient in $\mathrm{gr} \mathrm{ha}^{-1} \mathrm{yr}^{-1}$;

$\mathrm{IJI}_{\mathrm{G} 1}$ the interspersion juxtaposition index of the high-density grassland;

\begin{tabular}{|c|c|c|c|c|c|c|c|c|c|}
\hline \multicolumn{2}{|c|}{ Model } & \multicolumn{3}{|c|}{ Coefficients } & \multirow[b]{2}{*}{$r^{2}$} & \multirow[b]{2}{*}{$\mathbf{t}$} & \multirow[b]{2}{*}{ Sig. } & \multicolumn{2}{|c|}{ Collinearity Statistics } \\
\hline Model & Variable & B & Std. Error & Beta & & & & Tolerance & VIF \\
\hline \multirow{3}{*}{$\mathrm{SO}_{4}$} & Constant & -0.28 & 0.189 & & \multirow{3}{*}{0.5} & -1.482 & 0.014 & & \\
\hline & $\mathrm{IJI}_{\mathrm{G} 2}$ & -0.404 & 0.128 & -0.5 & & -3.166 & 0.004 & 1.000 & 1.000 \\
\hline & $\mathrm{IJI}_{\mathrm{G} 1}$ & -0.547 & 0.124 & -0.661 & & -4.409 & 0.000 & 1.000 & 1.000 \\
\hline \multirow{3}{*}{$\mathrm{HCO}_{3}$} & Constant & 2.537 & 0.095 & & \multirow{3}{*}{0.577} & 26.76 & 0.000 & & \\
\hline & Cohesion $_{\mathrm{Or}}$ & 0.168 & 0.055 & 0.463 & & 3.055 & 0.005 & 1.000 & 1.000 \\
\hline & Cohesion $_{\mathrm{Wb}}$ & 0.135 & 0.059 & 0.345 & & 2.274 & 0.031 & 1.000 & 1.000 \\
\hline \multirow{2}{*}{$\mathrm{Cl}$} & Constant & -0.724 & 0.145 & & \multirow{2}{*}{0.431} & -5.001 & 0.000 & & \\
\hline & Split $_{\text {Ir }}$ & -0.129 & 0.049 & -0.431 & & -2.614 & 0.014 & 1.000 & 1.000 \\
\hline \multirow{2}{*}{$\mathrm{Ca}$} & Constant & -0.71 & 0.124 & & \multirow{2}{*}{0.469} & -5.749 & 0.000 & & \\
\hline & Split $_{I r}$ & -0.122 & 0.042 & -0.469 & & -2.907 & 0.007 & 1.000 & 1.000 \\
\hline \multirow{2}{*}{$\mathrm{Mg}$} & Constant & 0.283 & 0.058 & & \multirow{2}{*}{0.574} & 4.905 & 0.000 & & \\
\hline & $\mathrm{IJI}_{\mathrm{G} 2}$ & -0.149 & 0.039 & -0.579 & & -3.836 & 0.001 & 1.000 & 1.000 \\
\hline \multirow{2}{*}{$\mathrm{Na}$} & Constant & -0.496 & 0.188 & & \multirow{2}{*}{0.505} & -2.638 & 0.013 & & \\
\hline & $\mathrm{IJI}_{\mathrm{G} 2}$ & -0.406 & 0.127 & -0.505 & & -3.201 & 0.003 & 1.000 & 1.000 \\
\hline
\end{tabular}

$\mathrm{IJI}_{\mathrm{G} 2}$ the interspersion juxtaposition index of the moderate density grassland;

$\mathrm{PCI}_{\mathrm{Or}}$ the patch cohesion index of the permanent crops;

$\mathrm{PCI}_{\mathrm{Wb}}$ the patch cohesion index of the water bodies;

$\mathrm{SI}_{\mathrm{Ir}}$ the splitting index of the permanently irrigated land.

Table 5. Details of the regression models of the water quality variables.

Our findings showed the interspersion juxtaposition index, patch cohesion index, and splitting index explained from $43 \%$ to $57 \%$ of the total variation in $\mathrm{CEC}_{\mathrm{Cl}}$ and $\mathrm{CEC}_{\mathrm{HCO}}$. The collinearity between independent variables was examined by the variance inflation factor $[61,62]$ and found no collinearity in the models made in this study, as all the VIFs are lower than 10 for the independent variables of the models (Table 5).

\subsubsection{Model Validation}

To validate the models, the predicted versus observed values were depicted, as were shown in the one-by-one relationships (Figure 4). Moreover, the results of the calculation of three error groups, which include the relative error metrics, efficiency metrics, and absolute error metrics, have been summarized in Table 6 . The models indicated a relatively moderate performance in predicting the $\mathrm{CEC}_{\mathrm{Na}}, \mathrm{CEC}_{\mathrm{SO}}, \mathrm{CEC}_{\mathrm{HCO}}, \mathrm{CEC}_{\mathrm{Ca}}$, and high performance in predicting the $\mathrm{CEC}_{\mathrm{Cl}}, \mathrm{CEC}_{\mathrm{Mg}}$ referring $r^{2}$ coefficients. 

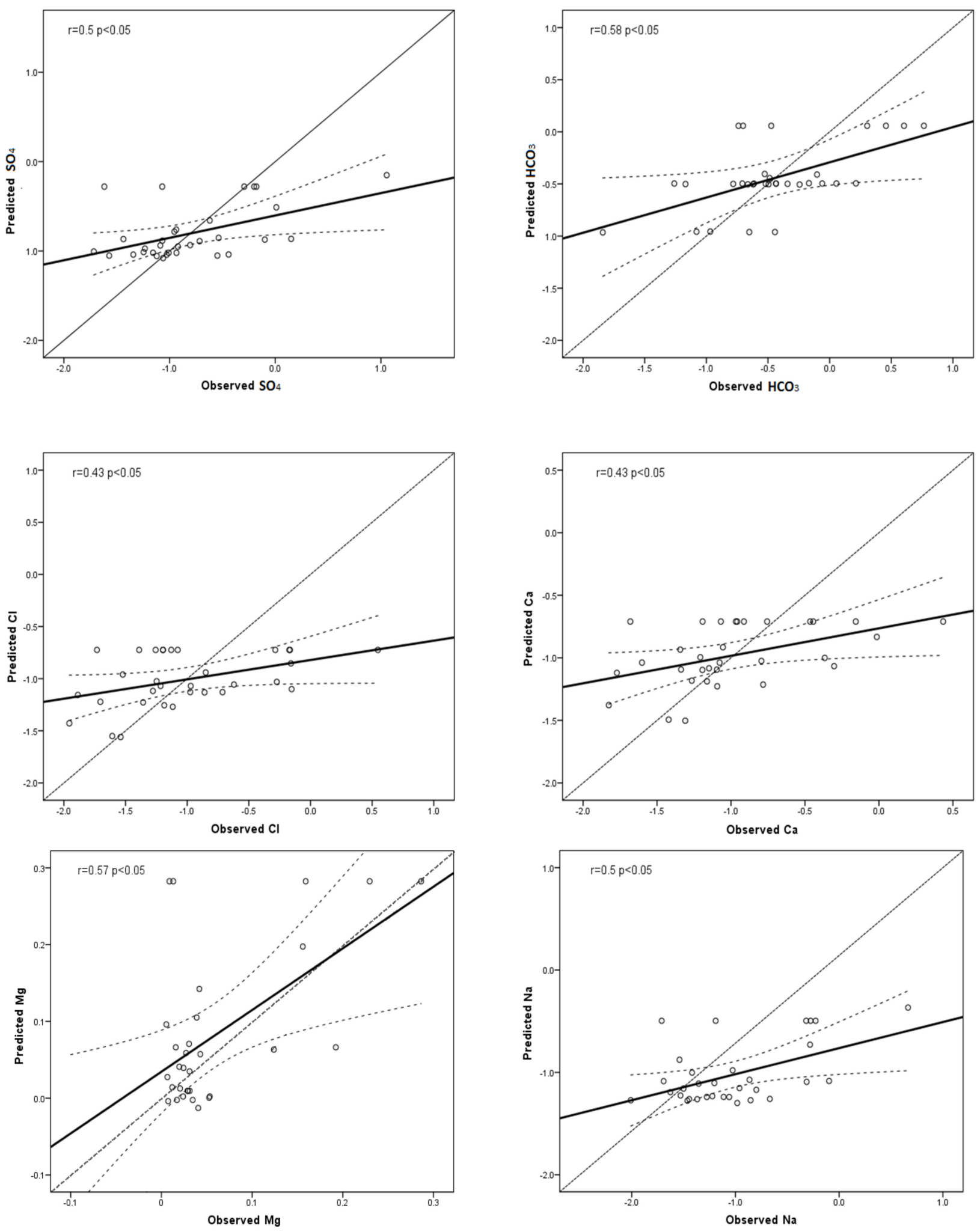

Figure 4. Observed vs. predicted values for water quality variables. 
Table 6. Values of the validation metrics for the regression models of the water quality variables.

\begin{tabular}{|c|c|c|c|c|c|c|c|c|c|c|c|}
\hline \multirow{2}{*}{ Model } & \multicolumn{4}{|c|}{ Relative Error Model } & \multicolumn{3}{|c|}{ Model Efficiency } & \multicolumn{4}{|c|}{ Absolute Error Model } \\
\hline & RVE & MRE & MARE & RAE & IA & $\mathrm{CE}$ & $\mathbf{r}^{2}$ & RMSE & ME & MAE & PDIFF \\
\hline $\mathrm{CEC}_{\mathrm{SO}_{4}}$ & 0.06 & -0.22 & -0.50 & 0.77 & 0.67 & 0.37 & 0.58 & 0.42 & -0.05 & 0.36 & 0.10 \\
\hline $\mathrm{CEC}_{\mathrm{HCO}_{3}}$ & 0.04 & 0.16 & -0.23 & 0.83 & 0.53 & 0.46 & 0.47 & 0.44 & -0.02 & 0.35 & 0.55 \\
\hline $\mathrm{CEC}_{\mathrm{Cl}}$ & -0.10 & -0.70 & -0.83 & 0.67 & 0.71 & 0.47 & 0.7 & 0.41 & 0.11 & 0.33 & 0.69 \\
\hline $\mathrm{CEC}_{\mathrm{Ca}}$ & -0.12 & -5.38 & -5.47 & 0.73 & 0.71 & 0.43 & 0.6 & 0.36 & 0.12 & 0.26 & 0.82 \\
\hline $\mathrm{CEC}_{\mathrm{Mg}}$ & -0.23 & -1.61 & 2.47 & 0.71 & 0.91 & 0.56 & 0.74 & 0.05 & -0.01 & 0.04 & 0.00 \\
\hline $\mathrm{CEC}_{\mathrm{Na}}$ & 0.03 & -0.22 & -0.46 & 0.79 & 0.50 & 0.42 & 0.44 & 0.41 & -0.03 & 0.38 & 0.27 \\
\hline
\end{tabular}

$\mathrm{MRE}=$ mean relative error $(\mathrm{MRE}), \mathrm{MARE}=$ mean absolute relative error, $\mathrm{RVE}=$ relative volumetric error $r^{2}=$ coefficient of determination, IA = consistency index, $\mathrm{CE}=$ coefficient of efficiency, RMSE $=$ root mean square error, $\mathrm{ME}=$ mean error, $\mathrm{MAE}=$ mean absolute error and $\mathrm{PDIFF}=$ peak difference.

\subsubsection{Uncertainty Analysis}

The results of the Monte Carlo simulation-based uncertainty analysis were summarized in Table 7. Accordingly, the results of the cumulative density function-based model behavioral analysis revealed that $(\mathrm{Pr}$ (output) $<0)$ is equal to 0 for $\mathrm{HCO}_{3}, \mathrm{Ca}, \mathrm{Mg}$ models, while it is five percent for the $\mathrm{SO}_{4}, \mathrm{Cl}$, and Na models (Table 7, Figure 5).

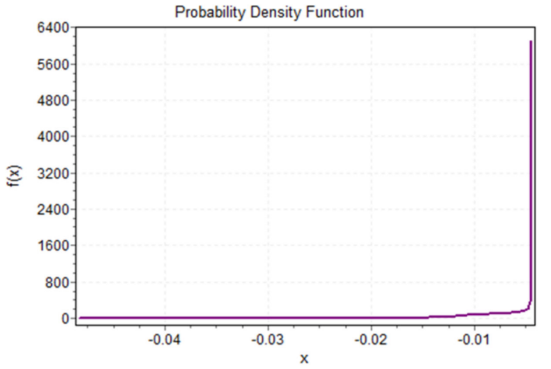

A Wakeby $(0.75601 ; 22.009 ; 0.01469 ;-1.5484 ;-0.04829)$

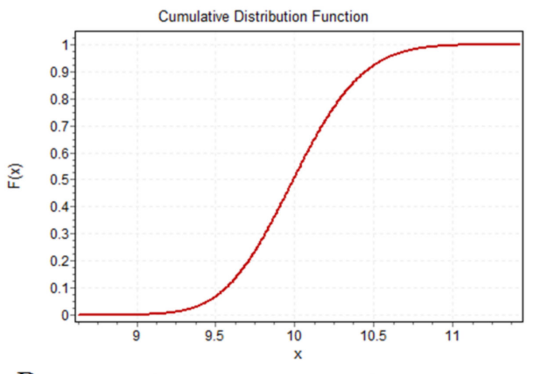

B

-Pearson $5(845.23 ; 8440.8)$

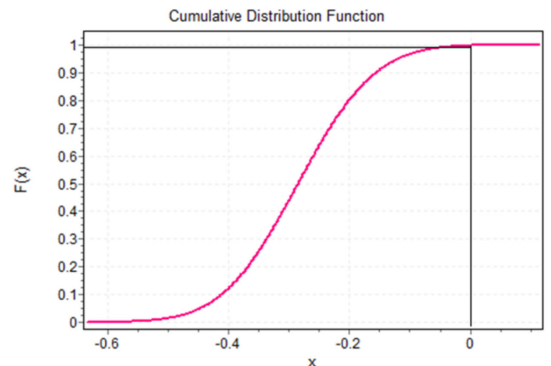

C

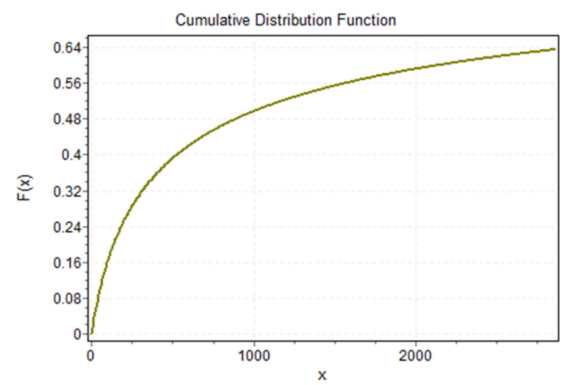

$\mathrm{D}$

- Burr $(0.33332 ; 0.9933 ; 142.68)$

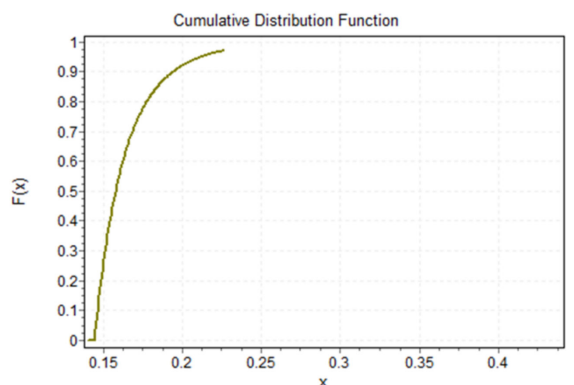

E - Burr (0.00497; 1573.8: 0.1446)

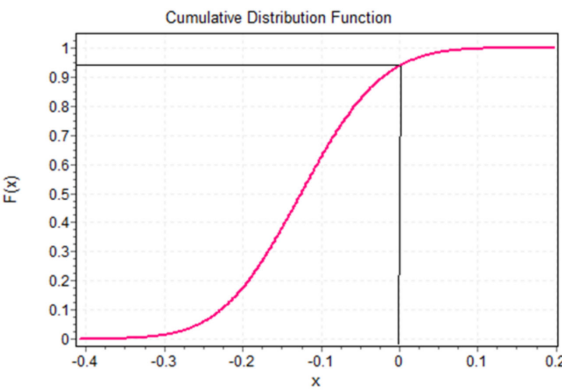

F $\quad$ - Inv. Gaussian (88838.0; 8.332; - 8.4577)

Figure 5. The cumulative density function for the simulated regression models (A): $\mathrm{SO}_{4},(\mathbf{B}): \mathrm{HCO}_{3}$, (C): Cl, (D): Ca, (E): $\mathrm{Mg}$, (F): $\mathrm{Na}$. 
Table 7. Results of optimal statistical distribution for the variables of the regression models.

\begin{tabular}{|c|c|c|c|c|c|c|}
\hline \multirow{2}{*}{ Variable } & & \multirow{2}{*}{$\begin{array}{l}\text { Model } \\
\text { Variable }\end{array}$} & \multirow{2}{*}{$\begin{array}{l}\text { Statistical } \\
\text { Distribution }\end{array}$} & \multicolumn{2}{|c|}{ Kolmogorov Smirnov } & \multirow{2}{*}{$\begin{array}{l}\text { Statistical } \\
\text { Variables }\end{array}$} \\
\hline & & & & Statistics & $p$-Value & \\
\hline \multirow{4}{*}{$\mathrm{SO}_{4}$} & \multirow{3}{*}{$\begin{array}{l}\text { A Prior } \\
\text { statistics }\end{array}$} & $\mathrm{IJI}_{\mathrm{G} 2}$ & Johnson SB & 0.08346 & 0.98378 & $\begin{array}{c}\gamma=-0.10234 \delta=0.60994 \\
\lambda=97.133 \xi=-2.9977\end{array}$ \\
\hline & & $\mathrm{IJI}_{\mathrm{G} 1}$ & Wake by & 0.09072 & 0.99345 & $\begin{array}{c}\alpha=99.644 \beta=1.3699 \gamma=0 \\
\delta=0 \xi=7.8798\end{array}$ \\
\hline & & $Y_{\text {obs. }}$ & Frechet & 0.09937 & 0.87942 & $\alpha=0.99839 \beta=0.07982$ \\
\hline & $\begin{array}{l}\text { Posterior } \\
\text { statistics }\end{array}$ & $\mathrm{Y}_{\text {Sim }}$ & Wake by & 0.03796 & $5.96 \times 10^{-19}$ & $\begin{array}{c}\alpha=0.75601 \beta=22.009 \gamma=0.01469 \\
\delta=-1.5484 \xi=-0.04829\end{array}$ \\
\hline \multirow{3}{*}{$\mathrm{HCO}_{3}$} & \multirow{2}{*}{$\begin{array}{l}\text { A Prior } \\
\text { statistics }\end{array}$} & Cohesionor & Wakeby & 0.0912 & 0.97762 & $\begin{array}{c}\alpha=26656.0 \beta=72.288 \gamma=6.4426 \\
\delta=-0.55069 \xi=-280.07\end{array}$ \\
\hline & & $\begin{array}{l}\text { Cohesion }_{\mathrm{Wb}} \\
\mathrm{Y}_{\mathrm{obs}}\end{array}$ & $\begin{array}{l}\text { Uniform } \\
\text { Pearson } 5\end{array}$ & $\begin{array}{c}0.125 \\
0.19734\end{array}$ & $\begin{array}{l}0.9976 \\
0.1442\end{array}$ & $\begin{array}{c}\mathrm{m}=1151 \beta=0.08185 \\
\alpha=0.7473 \beta=0.12129\end{array}$ \\
\hline & $\begin{array}{l}\text { Posterior } \\
\text { statistics }\end{array}$ & $\mathrm{Y}_{\text {Sim. }}$ & Pearson 5 & 0.34757 & 0.00 & $\alpha=845.23 \beta=8440.8$ \\
\hline \multirow{3}{*}{$\mathrm{Cl}$} & \multirow{2}{*}{$\begin{array}{l}\text { A Prior } \\
\text { statistics }\end{array}$} & Split $_{I r}$ & Pearson 6 & 0.08581 & 0.99407 & $\begin{array}{c}\alpha_{1}=5.7212 \alpha_{2}=0.33045 \\
\beta=21.137 \gamma=-28.329\end{array}$ \\
\hline & & $\mathrm{Y}_{\text {obs }}$ & $\begin{array}{l}\text { Inv. Gaussian } \\
\qquad(3 \mathrm{P})\end{array}$ & 0.09307 & 0.9204 & $\lambda=0.04932 \mu=0.28182 \gamma=0.00353$ \\
\hline & $\begin{array}{l}\text { Posterior } \\
\text { statistics }\end{array}$ & $\mathrm{Y}_{\text {Sim. }}$ & $\begin{array}{l}\text { Inv. Gaussian } \\
\qquad(3 \mathrm{P})\end{array}$ & 0.02123 & $2.89 \times 10^{-6}$ & $\lambda=2.3836 \times 10^{5} \mu=13.324 \gamma=-13.609$ \\
\hline \multirow{3}{*}{$\mathrm{Ca}$} & \multirow{3}{*}{$\begin{array}{l}\text { A Prior } \\
\text { statistics } \\
\text { Posterior } \\
\text { statistics }\end{array}$} & Split $_{I r}$ & Pearson 6 & 0.08581 & 0.99407 & $\begin{array}{c}\alpha_{1}=5.7212 \alpha_{2}=0.33045 \\
\beta=21.137 \gamma=-28.329\end{array}$ \\
\hline & & $\mathrm{Y}_{\text {obs. }}$ & Burr & 0.09237 & 0.92441 & $k=0.40063 \alpha=2.4943 \beta=0.0475$ \\
\hline & & $\mathrm{Y}_{\text {Sim. }}$ & Dagum (4P) & 0.00385 & 0.97892 & $\begin{array}{c}k=0.3349 \alpha=8.1496 \\
\beta=0.54693 \gamma=-0.71143\end{array}$ \\
\hline \multirow{3}{*}{ Mg } & \multirow{2}{*}{$\begin{array}{l}\text { A Prior } \\
\text { statistics }\end{array}$} & $\mathrm{IJI}_{\mathrm{G} 2}$ & Johnson SB & 0.10208 & 0.8593 & $\begin{array}{c}\gamma=-0.10234 \delta=0.60994 \\
\lambda=97.133 \xi=-2.9977\end{array}$ \\
\hline & & $\mathrm{Y}_{\mathrm{obs}}$ & Burr & 0.09879 & 0.88354 & $\mathrm{k}=0.41424 \alpha=2.4282 \beta=0.01708$ \\
\hline & $\begin{array}{l}\text { Posterior } \\
\text { statistics }\end{array}$ & $\mathrm{Y}_{\text {Sim. }}$ & Burr & 0.099 & 0.00 & $\mathrm{k}=0.00497 \alpha=1573.8 \beta=0.1446$ \\
\hline \multirow{3}{*}{$\mathrm{Na}$} & \multirow{2}{*}{$\begin{array}{l}\text { A Prior } \\
\text { statistics }\end{array}$} & $\mathrm{IJI}_{\mathrm{G} 2}$ & Johnson SB & 0.08346 & 0.98378 & $\begin{array}{c}\gamma=-0.08501 \delta=0.59234 \\
\lambda=98.99 \xi=-5.2629\end{array}$ \\
\hline & & $Y_{\text {obs. }}$ & $\begin{array}{l}\text { Inv. Gaussian } \\
\qquad(3 \mathrm{P})\end{array}$ & 0.08543 & 0.95797 & $\lambda=0.04959 \mu=0.30093 \gamma=0.00351$ \\
\hline & $\begin{array}{l}\text { Posterior } \\
\text { statistics }\end{array}$ & $\mathrm{Y}_{\text {Sim. }}$ & $\begin{array}{l}\text { Inv. Gaussian } \\
\text { (3P) }\end{array}$ & 0.27944 & 0.00 & $\lambda=88838.0 \mu=8.332 \gamma=-8.4577$ \\
\hline
\end{tabular}

\section{Discussion}

Rivers are considered as one of the important paths and sinks for the accumulation and transfer of nutrients and pollutants that are released from the surrounding landscape [63]. The quality of surface water can then be related to the characteristics of the composition, structure, and configuration of the landscape and is therefore very sensitive to human activities performed in catchments [64]. The concepts of landscape ecology have been contributing to other scientific areas, such as hydrology in the re-justification of major processes, including runoff generation [13], water quality [1], water quantity $[65,66]$, timerelated processes such as lag time [14], and flooding as one of the catchment responses [67]. Therefore, the landscape approach can be considered as one of the most appropriate approaches in addressing the hydrological processes at the catchment scale. Changes in landscape features, such as composition, structure, and configuration can have significant effects on ecological processes in general and hydrological processes in particular due to disruption in natural cycles. One of the most important natural cycle disorders is the acceleration and intensification of pollutant effluents and nutrients leaching in aquatic environments, such as rivers, lakes, and wetlands [63]. The results of this study show that 
if the landscape configuration is considered during the implementation of land-use plans, it can be applied to regulate the water quality of surface water resources, such as rivers. Previous works (e.g., see: [68]) indicated that the study area has undergone an extensive change in the land use/land cover composition during the years between 1987-2015, so the shares of bare and residential lands increased $32 \%$ and 50\%, respectively. Moreover, the non-irrigated arable land and permanently irrigated lands have also experienced $1 \%$ and 3\% increases, respectively. Meanwhile, the share of the grasslands in the landscape composition has decreased from 58 to $53 \%$ in the same period. These significant changes in land use/land cover composition, which might mainly be due to population growth and changes in the income portfolio of local people, have led to shrinkage in the area of natural ecosystems, such as the broad-leaved forests and grasslands.

The result indicates that the CEC of sulfate was indirectly related to the interspersion juxtaposition index of the high-density and moderate-density grasslands. The interspersion juxtaposition index, by definition, shows the patches of each land use/land cover and how far or close they are to each other at the landscape class level. It measures patch cohesion degree based on patch proximity to each other [28] and varies between 0 and 100 , implying the higher the value of interspersion juxtaposition index, the higher the patch proximity of the land use/land cover of interest. Increasing the proximity of the high-density and moderate-density grassland patches is significantly associated with a decrease in the CEC of sulfate. This suggests that the discontinuity of the grasslands could increase the CEC of sulfate and thus degrade the river water quality in the study catchments. However, the findings of Shen et al. (2014) contradict our findings, as they showed a positive relationship between water quality variables and the interspersion juxtaposition index [69]. This contradiction could likely be originated from differences in the soil types, that of bedrocks (gypsum-containing ones), atmospheric, and industrial sources in the study areas, which are interconnected.

The CECs of bicarbonate were positively associated with the patch cohesion index of the permanent crops and that of the water body. Accordingly, if the patch cohesion index of the permanent crops and that of the water bodies increase, the bicarbonate export coefficient increases in the study catchments. The patch cohesion metric is an indicator, by which the dispersion degree of patches is measured, and is correlated to dispersal positions [21]. This metric can be expressed to understand the integration of similar land use/land cover types and thus provides practical information about landscape configuration [29]. The value of the index gets to zero once the patches of a given land use/land cover type are very isolated, and increases when the patches are much more aggregated [29]. This means, implicitly, that if the patch cohesion of the permanent crops and that of the water bodies increase, the CEC of bicarbonate will increase across the study catchments. Moreover, bicarbonate is highly affected by carbonate weathering [70,71], which can contribute to the bicarbonate washout from the terrestrial ecosystems and entering aquatic environments, such as rivers.

The results show that $43-47 \%$ of the total variability in the CECs of chlorine and calcium were significantly explained by the change in the split index of the permanently irrigated land, respectively. Both models revealed that there is an indirect relationship between the CEC of chlorine and that of calcium with the split index of the permanently irrigated lands. The discontinuity degree of the patches of a given land use/land cover can be measured by the split index. For a given landscape, the higher the split index value, the more discontinuous patches [72]. While chlorine is one of the chemical elements, whose concentration in water resources increases in proportion to the human population growth; geological formations, pesticides, power plants, wastewater treatment plants, industries, along with atmospheric resources are also accounted as contributing sources of chlorine. Equations (6) and (7) unveiled that the continuity of the permanently irrigated land patches can increase the CECs of chlorine and calcium and thus degrade river water quality. Ahearn et al. (2005) and Turner and Rabalais (2003) indicated that agricultural land pattern has a direct effect on sedimentation rate $[57,73]$. In the areas with the permanently irrigated lands, soil erosion due to plowing, planting, and harvesting measures, is an important factor in 
increasing the concentration of contaminants in surface water, because bare soils, due to the decrease in the number of local controls compared to vegetated soils, transfer nutrients more quickly to surface waters. Calcium is one of the most abundant elements in aquatic environments. The presence of limestone and gypsum in the earth's crust is accounted as the main source of calcium, which is washed out into the surface waters [74]. Industrial processes and wastewater disposal centers also play a significant role in releasing calcium into surface waters [75]. Shi et al. (2017) showed that urban and agricultural land uses are inversely associated with instream water quality, while forest and grassland contribute to improving river water quality [76], which is consistent with the findings of [77,78].

Table 5 shows that $50-57 \%$ of the total variation in the CECs of sodium and magnesium were expressed by change in the interspersion juxtaposition index of the moderatedensity grassland patches. The CECs of magnesium and that of sodium were inversely associated with the interspersion juxtaposition index. Implicitly, the discontinuity of the moderate-density grassland patches degrades the river water quality in the study catchments by accelerating the magnesium and sodium washouts from the terrestrial ecosystems into rivers. Landscape configuration has an important role in nutrient runoff from the catchment [79]. Shen et al. (2014) have also shown an inverse relationship between the interspersion juxtaposition index and unused land, which are in contrast with those of this study [69]. Sullivan et al. (2004) suggested that the division of land into smaller plots may lead to an increase in the number of junctions amongst drains, which will thus increase surface and subsurface flows and consequently cause washing of more pollutants and nutrients out into the aquatic ecosystem, such as rivers, lakes, and wetlands [80].

\section{Conclusions}

Our findings showed that the cohesion and coherence of the permanently irrigated land patches that resulted in the discontinuity of the grassland and broad-leaved forest ecosystems could be considered as one of the main factors in degrading the river water quality in the study catchments. They also indicated that the discontinuity and degree of proximity of pieces of a land use/land cover type, by which landscape configuration is analyzed and interpreted, could be one of the main concerns during any land-use planning process. In this regard, the analytical framework developed in this study can provide an implicative tool in identifying the water quality degradation risks and will allow for appropriate land-use planning, aiming at restoring and maintaining water quality. It can also be applied in policymaking for the sustainable development of the aquatic environments in rapidly urbanizing areas, formulating policy recommendations for water resources governance. The regression models presented in this study might not be affected by the hydrological fluctuations, since to develop those models, four year mean values of the water quality variables were applied. The multiple regression models which were developed, have the coefficients of determination of 0.43 to 0.57 . The application of the models is strictly limited to the range of the variables in the models and for catchments whose areas might vary between 3.73 to $3242.67 \mathrm{~km}^{2}$. Applying the models for the smaller catchments could then be associated with the interferences of some local controls, while for the larger catchments, the models might be exposed to some aggregations in the controlling factors.

Author Contributions: Conceptualization, B.J.A. and M.A.; methodology, B.J.A.; validation, M.A.; formal analysis, M.A.; investigation, M.A.; resources, M.A.; data curation, M.A.; writing-original draft preparation, M.A., E.A. and T.D.; writing-review and editing, B.J.A., E.A. and T.D.; visualization, M.A.; supervision, B.J.A.; project administration, B.J.A. All authors have read and agreed to the published version of the manuscript.

Funding: No funding was received to assist with the preparation of this manuscript.

Institutional Review Board Statement: Not applicable.

Informed Consent Statement: Not applicable. 
Data Availability Statement: All data, models, and code generated or used during the study appear in the submitted article.

Acknowledgments: We are grateful for Ardabil Regional Authority of Water Resources Management and Ardabil Management and Planning Organization for providing us with digital spatial data of this study.

Conflicts of Interest: The authors declare no conflict of interest.

\section{References}

1. Xu, G.; Ren, X.; Yang, Z.; Long, H.; Xiao, J. Influence of Landscape Structures on Water Quality at Multiple Temporal and Spatial Scales: A Case Study of Wujiang River Watershed in Guizhou. Water 2019, 11, 159. [CrossRef]

2. Aalipour, M.; Gasempour Niari, H.; Mousavi Meshkini, S.R.; Foroug, S. Surveying drinking water quality (Balikhlou River, Ardabil Province, Iran). Appl. Water Sci. 2018, 8, 1-7. [CrossRef]

3. Xu, H.; Zheng, H.; Chen, X.; Ren, Y.; Ouyang, Z. Relationships between river water quality and landscape factors in Haihe River Basin, China: Implications for environmental management. Chin. Geogr. Sci. 2016, 26, 197-207. [CrossRef]

4. Lintern, A.; Webb, J.; Ryu, D.; Liu, S.; Bende-Michl, U.; Waters, D.; Leahy, P.; Wilson, P.; Western, A. Key factors influencing differences in stream water quality across space. Wiley Interdiscip. Rev. Water 2018, 5, e1260. [CrossRef]

5. $\quad$ Lin, Y.-P.; Verburg, P.H.; Chang, C.-R.; Chen, H.-Y.; Chen, M.-H. Developing and comparing optimal and empirical land-use models for the development of an urbanized watershed forest in Taiwan. Landsc. Urban Plan. 2009, 92, 242-254. [CrossRef]

6. Tanaka, M.O.; de Souza, A.L.T.; Moschini, L.E.; de Oliveira, A.K. Influence of watershed land use and riparian characteristics on biological indicators of stream water quality in southeastern Brazil. Agric. Ecosyst. Environ. 2016, 216, 333-339. [CrossRef]

7. Hao, F.; Zhang, X.; Wang, X.; Ouyang, W. Assessing the Relationship Between Landscape Patterns and Nonpoint-Source Pollution in the Danjiangkou Reservoir Basin in China 1. JAWRA J. Am. Water Resour. Assoc. 2012, 48, 1162-1177. [CrossRef]

8. Hartmann, J.; Moosdorf, N.; Lauerwald, R.; Hinderer, M.; West, A.J. Global chemical weathering and associated P-release-The role of lithology, temperature and soil properties. Chem. Geol. 2014, 363, 145-163. [CrossRef]

9. Jiang, J.; Sharma, A.; Sivakumar, B.; Wang, P. A global assessment of climate-water quality relationships in large rivers: An elasticity perspective. Sci. Total Environ. 2014, 468-469, 877-891. [CrossRef]

10. Alberti, M.; Booth, D.; Hill, K.; Coburn, B.; Avolio, C.; Coe, S.; Spirandelli, D. The impact of urban patterns on aquatic ecosystems: An empirical analysis in Puget lowland sub-basins. Landsc. Urban Plan. 2007, 80, 345-361. [CrossRef]

11. Xie, Y.; Yu, X.; Ng, N.C.; Li, K.; Fang, L. Exploring the dynamic correlation of landscape composition and habitat fragmentation with surface water quality in the Shenzhen river and deep bay cross-border watershed, China. Ecol. Indic. 2018, 90, 231-246. [CrossRef]

12. Oliveira, J.; Becegato, V.R.; Barcarolli, I.F.; Paulino, A.; Becegato, V. Environmental Characteristics and Water Quality of a Drainage Basin Impacted by Human Activities. Environmental Mangment and Sustainable Development; Routledge: London, UK, 2017; Volume 6, p. 373.

13. Zhang, X.; Liu, Y.; Zhou, L. Correlation analysis between landscape metrics and water quality under multiple scales. Int. J. Environ. Res. Public Health 2018, 15, 1606. [CrossRef] [PubMed]

14. Amiri, B.J.; Gao, J.; Fohrer, N.; Adamowski, J.; Huang, J. Examining lag time using the landscape, pedoscape and lithoscape metrics of catchments. Ecol. Indic. 2019, 105, 36-46. [CrossRef]

15. Caja, C.; Ibunes, N.; Paril, J.; Reyes, A.; Nazareno, J.; Monjardin, C.; Uy, F. Effects of land cover changes to the quantity of water supply and hydrologic cycle using water balance models. In Proceedings of the MATEC Web of Conferences, Melaka, Malysia, 23 February 2018; p. 06004.

16. Aalipour Ardi, M.; Jabbarian Amiri, B. Investigating the Effects of Land Use/Land Cover Composition on River Water Quality. J. Civ. Environ. Eng. 2021, 51, 83-93.

17. Guo, L. Analysis of spatio-temporal changes in the landscape pattern of the Taishan mountain. J. Mt. Ecol. 2006, 8, 1-6.

18. Lee, S.-W.; Hwang, S.-J.; Lee, S.-B.; Hwang, H.S.; Sung, H.-C. Landscape ecological approach to the relationships of land use patterns in watersheds to water quality characteristics. Landsc. Urban Plan. 2009, 92, 80-89. [CrossRef]

19. Forman, R.; Gordon, M. Landscape Ecology; John Wiley: New York, NY, USA, 1986; p. 619.

20. Verhagen, W.; Van Teeffelen, A.J.; Compagnucci, A.B.; Poggio, L.; Gimona, A.; Verburg, P.H. Effects of landscape configuration on mapping ecosystem service capacity: A review of evidence and a case study in Scotland. Landsc. Ecol. 2016, 31, 1457-1479. [CrossRef]

21. Rutledge, D.T. Landscape Indices as Measures of the Effects of Fragmentation: Can Pattern Reflect Process? Department of Conservation: Wellington, New Zealand, 2003.

22. Del Tánago, M.G.; Gurnell, A.; Belletti, B.; De Jalón, D.G. Indicators of river system hydromorphological character and dynamics: Understanding current conditions and guiding sustainable river management. Aquat. Sci. 2016, 78, 35-55. [CrossRef]

23. Zhou, T.; Ren, W.; Peng, S.; Liang, L.; Ren, S.; Wu, J. A riverscape transect approach to studying and restoring river systems: A case study from southern China. Ecol. Eng. 2014, 65, 147-158. [CrossRef]

24. Amiri, B.J.; Nakane, K. Modeling the linkage between river water quality and landscape metrics in the Chugoku district of Japan. Water Resour. Manag. 2009, 23, 931-956. [CrossRef] 
25. Evans, I.S.; Robinson, D.T.; Rooney, R.C. A methodology for relating wetland configuration to human disturbance in Alberta. Landsc. Ecol. 2017, 32, 2059-2076. [CrossRef]

26. Snyder, M.N.; Goetz, S.J.; Wright, R.K. Stream health rankings predicted by satellite derived land cover metrics 1 . JAWRA J. Am. Water Resour. Assoc. 2005, 41, 659-677. [CrossRef]

27. Hu, X.; Wang, H.; Zhu, Y.; Xie, G.; Shi, H. Landscape characteristics affecting spatial patterns of water quality variation in a highly disturbed region. Int. J. Environ. Res. Public Health 2019, 16, 2149. [CrossRef] [PubMed]

28. McGarigal, K.; Marks, B.J. Spatial pattern analysis program for quantifying landscape structure. In General Technical Report. PNW-GTR-351; US Department of Agriculture, Forest Service, Pacific Northwest Research Station: Portland, OR, USA, 1995; pp. 1-122.

29. Schumaker, N.H. Using landscape indices to predict habitat connectivity. Ecology 1996, 77, 1210-1225. [CrossRef]

30. Jaeger, J.A. Landscape division, splitting index, and effective mesh size: New measures of landscape fragmentation. Landsc. Ecol. 2000, 15, 115-130. [CrossRef]

31. Omernik, J.M. The Influence of Land Use on Stream Nutrient Levels; US Environmental Protection Agency, Office of Research and Development: Washington, DC, USA, 1976.

32. Norvell, W.; Frink, C.; Hill, D. Phosphorus in Connecticut lakes predicted by land use. Proc. Natl. Acad. Sci. USA 1979, 76, 5426-5429. [CrossRef]

33. Beaulac, M.; Reckhow, K. An examination of land use: Nutrient export relationships [Phosphorus, nonpoint source pollution, agricultural, forest, urban, watershed]. Water Resour. Bull. 1982, 18, 1013-1024-1024. [CrossRef]

34. Kronvang, B.; Bechmann, M.; Lundekvam, H.; Behrendt, H.; Rubaek, G.; Schoumans, O.; Syversen, N.; Andersen, H.; Hoffmann, C. Phosphorus losses from agricultural areas in river basins: Effects and uncertainties of targeted mitigation measures. J. Environ. Qual. 2005, 34, 2129-2144. [CrossRef]

35. Walling, D.; Webb, B. Estimating the discharge of contaminants to coastal waters by rivers: Some cautionary comments. Mar. Pollut. Bull. 1985, 16, 488-492. [CrossRef]

36. Johnes, P.J. Evaluation and management of the impact of land use change on the nitrogen and phosphorus load delivered to surface waters: The export coefficient modelling approach. J. Hydrol. 1996, 183, 323-349. [CrossRef]

37. Mattikalli, N.M.; Richards, K.S. Estimation of surface water quality changes in response to land use change: Application of the export coefficient model using remote sensing and geographical information system. J. Environ. Manag. 1996, 48, 263-282. [CrossRef]

38. Chen, J.; Lu, J. Effects of land use, topography and socio-economic factors on river water quality in a mountainous watershed with intensive agricultural production in East China. PLoS ONE 2014, 9, e102714.

39. Li, S.; Yang, H.; Lacayo, M.; Liu, J.; Lei, G. Impacts of land-use and land-cover changes on water yield: A case study in Jing-Jin-Ji, China. Sustainability 2018, 10, 960. [CrossRef]

40. Wu, L.; Gao, J.-E.; Ma, X.-Y.; Li, D. Application of modified export coefficient method on the load estimation of non-point source nitrogen and phosphorus pollution of soil and water loss in semiarid regions. Environ. Sci. Pollut. Res. 2015, 22, 10647-10660. [CrossRef] [PubMed]

41. Correll, D.L. The role of phosphorus in the eutrophication of receiving waters: A review. J. Environ. Qual. 1998, 27, 261-266. [CrossRef]

42. Matias, N.-G.; Johnes, P.J. Catchment phosphorous losses: An export coefficient modelling approach with scenario analysis for water management. Water Resour. Manag. 2012, 26, 1041-1064. [CrossRef]

43. Sun, Y.; Guo, Q.; Liu, J.; Wang, R. Scale effects on spatially varying relationships between urban landscape patterns and water quality. Environ. Manag. 2014, 54, 272-287. [CrossRef]

44. Bu, H.; Meng, W.; Zhang, Y.; Wan, J. Relationships between land use patterns and water quality in the Taizi River basin, China. Ecol. Indic. 2014, 41, 187-197. [CrossRef]

45. MPO, A. Ardabil Province Landuse Planning Manage Report; Ardabil Province Management and Planning Organization: Ardabil, Iran, 2012.

46. Iran National Cartographic Center. Topographic map of Iran (1:50000); Iran National Cartographic Center: Tehran, Iran, 2011.

47. European Environment Agency. CORINE Land Cover Product User Manual (Version 1.0); European Environment Agency: København, Denmark, 2021.

48. McGarigal, K.; Cushman, S.; Ene, E. Spatial Pattern Analysis Program for Categorical and Continuous Maps. Computer Software Program Produced by the Authors at the University of Massachusetts, Amherst. FRAGSTATS v4. Available online: http:/ / wwwumassedu/landeco/research/fragstats/fragstatshtml (accessed on 30 January 2022).

49. He, H.S.; DeZonia, B.E.; Mladenoff, D.J. An aggregation index (AI) to quantify spatial patterns of landscapes. Landsc. Ecol. 2000, 15, 591-601. [CrossRef]

50. Griffith, J.A. Geographic techniques and recent applications of remote sensing to landscape-water quality studies. Water Air Soil Pollut. 2002, 138, 181-197. [CrossRef]

51. Aithal, B.H.; Vinay, S.; Ramachandra, T. Prediction of Land Use Dynamics in the Rapidly Urbanising Landscape Using Land Change Modeler; AETACS: Delhi, India, 2013.

52. Amiri, B.J.; Gao, J.; Fohrer, N.; Adamowski, J. Regionalizing time of concentration using landscape structural patterns of catchments. J. Hydrol. Hydromech. 2019, 67, 135-142. [CrossRef] 
53. Delkash, M.; Al-Faraj, F.A.; Scholz, M. Comparing the export coefficient approach with the soil and water assessment tool to predict phosphorous pollution: The Kan watershed case study. Water Air Soil Pollut. 2014, 225, 1-17. [CrossRef]

54. Thompson, C.G.; Kim, R.S.; Aloe, A.M.; Becker, B.J. Extracting the variance inflation factor and other multicollinearity diagnostics from typical regression results. Basic Appl. Soc. Psychol. 2017, 39, 81-90. [CrossRef]

55. Portet, S. A primer on model selection using the Akaike Information Criterion. Infect. Dis. Model. 2020, 5, 111-128. [CrossRef] [PubMed]

56. Amiri, B.J.; Junfeng, G.; Fohrer, N.; Mueller, F.; Adamowski, J. Regionalizing flood magnitudes using landscape structural patterns of catchments. Water Resour. Manag. 2018, 32, 2385-2403. [CrossRef]

57. Ahearn, D.S.; Sheibley, R.W.; Dahlgren, R.A.; Anderson, M.; Johnson, J.; Tate, K.W. Land use and land cover influence on water quality in the last free-flowing river draining the western Sierra Nevada, California. J. Hydrol. 2005, 313, 234-247. [CrossRef]

58. Rykiel, E.J., Jr. Testing ecological models: The meaning of validation. Ecol. Model. 1996, 90, 229-244. [CrossRef]

59. Dawson, C.; Abrahart, R.J.; See, L.M. HydroTest: A web-based toolbox of evaluation metrics for the standardised assessment of hydrological forecasts. Environ. Model. Softw. 2007, 22, 1034-1052. [CrossRef]

60. Convertino, M.; Muñoz-Carpena, R.; Chu-Agor, M.L.; Kiker, G.A.; Linkov, I. Untangling drivers of species distributions: Global sensitivity and uncertainty analyses of MaxEnt. Environ. Model. Softw. 2014, 51, 296-309. [CrossRef]

61. Chatterjee, S.; Hadi, A.S. Regression Analysis by Example; John Wiley \& Sons: Hoboken, NJ, USA, 2015.

62. Neter, J.; Kutner, M.H.; Nachtsheim, C.J.; Wasserman, W. Applied Linear Statistical Models; Irwin: Chicago, IL, USA, $1996 ;$ Volume 4.

63. Shen, Z.; Hou, X.; Li, W.; Aini, G.; Chen, L.; Gong, Y. Impact of landscape pattern at multiple spatial scales on water quality: A case study in a typical urbanised watershed in China. Ecol. Indic. 2015, 48, 417-427. [CrossRef]

64. Sharma, P.; Gupta, G.; Prabhakar, P.; Tiwari, S.; Kathait, P.; Pathak, Y.; Mishra, N.; Kumar, S. Land use land cover change impact on water resources-A Review. Int. J. Adv. Eng. Sci. Res. 2017, 4, 7-14.

65. Amiri, B.J.; Fohrer, N.; Cullmann, J.; Hörmann, G.; Müller, F.; Adamowski, J. Regionalization of tank model using landscape metrics of catchments. Water Resour. Manag. 2016, 30, 5065-5085. [CrossRef]

66. Chiambretto, A.-S.; Martin, E. Water Quantity Management in a Heterogeneous Landscape with Farsighted Farmers. Environ. Resour. Econ. 2020, 77, 593-613. [CrossRef]

67. Sofia, G.; Nikolopoulos, E. Floods and rivers: A circular causality perspective. Sci. Rep. 2020, 10, 5175. [CrossRef]

68. Kakehmami, A. Land Use Change Detection of Ardabil Province in Last Two Decades Using Visual and Digital Interpretation of Sattelite Imagery; University of Mohaghegh Ardabili: Ardabil, Iran, 2016.

69. Shen, Z.; Hou, X.; Li, W.; Aini, G. Relating landscape characteristics to non-point source pollution in a typical urbanized watershed in the municipality of Beijing. Landsc. Urban Plan. 2014, 123, 96-107. [CrossRef]

70. Bleam, W.F. Soil and Environmental Chemistry; Academic Press: Cambridge, MA, USA, 2016.

71. Zhong, J.; Li, S.L.; Ibarra, D.E.; Ding, H.; Liu, C.Q. Solute production and transport processes in Chinese monsoonal rivers: Implications for global climate change. Glob. Biogeochem. Cycles 2020, 3, 4e2020GB006541. [CrossRef]

72. Shi, Z.; Ai, L.; Li, X.; Huang, X.; Wu, G.; Liao, W. Partial least-squares regression for linking land-cover patterns to soil erosion and sediment yield in watersheds. J. Hydrol. 2013, 498, 165-176. [CrossRef]

73. Turner, R.E.; Rabalais, N.N. Linking landscape and water quality in the Mississippi River basin for 200 years. Bioscience 2003, 53, 563-572. [CrossRef]

74. Day, F.H. Chemical Elements in Nature; George Harrup: London, UK, 1963.

75. Neel, M.C.; McGarigal, K.; Cushman, S.A. Behavior of class-level landscape metrics across gradients of class aggregation and area. Landsc. Ecol. 2004, 19, 435-455. [CrossRef]

76. Shi, P.; Zhang, Y.; Li, Z.; Li, P.; Xu, G. Influence of land use and land cover patterns on seasonal water quality at multi-spatial scales. Catena 2017, 151, 182-190. [CrossRef]

77. Li, S.; Liu, W.; Gu, S.; Cheng, X.; Xu, Z.; Zhang, Q. Spatio-temporal dynamics of nutrients in the upper Han River basin, China J. Hazard. Mater. 2009, 162, 1340-1346. [CrossRef] [PubMed]

78. Wan, R.; Cai, S.; Li, H.; Yang, G.; Li, Z.; Nie, X. Inferring land use and land cover impact on stream water quality using a Bayesian hierarchical modeling approach in the Xitiaoxi River Watershed, China. J. Environ. Manag. 2014, 133, 1-11. [CrossRef] [PubMed]

79. Uuemaa, E.; Antrop, M.; Roosaare, J.; Marja, R.; Mander, Ü. Landscape metrics and indices: An overview of their use in landscape research. Living Rev. Landsc. Res. 2009, 3, 1-28. [CrossRef]

80. Sullivan, A.; Ternan, J.; Williams, A. Land use change and hydrological response in the Camel catchment, Cornwall. Appl. Geogr. 2004, 24, 119-137. [CrossRef] 